\title{
Perbedaan Rerata Kadar Resistin dan TNF-A Antara Wanita Hamil Yang Obesitas dengan yang Memiliki Berat Badan Normal Pada Preeklamsi Berat Awitan Lambat
}

\author{
Ira Suryanis ${ }^{1}$, Eva Decroli ${ }^{2}$, Yusrawati $^{3}$, Eryati Darwin $^{4}$
}

\begin{abstract}
Abstrak
Faktor maternal merupakan pencetus Preeklamsi Awitan Lambat (PEAL). Salah satu faktor maternal adalah resistin, TNF- $\alpha$ yang dihubungkan dengan inflamasi dan resistensi insulin.. Tujuan penelitian ini adalah mengetahui perbedaan rerata kadar Resistin dan TNF- $\alpha$ maternal antara wanita hamil obesitas dan berat badan normal pada Preeklamsi Berat Awitan Lambat. Desain penelitian ialah comparative cross sectional yang dilakukan di RSUP Dr. M Djamil dan Laboratorium Biomedik Fakultas Kedokteran Universitas Andalas Padang dari Februari 2016 sampai Januari 2017. Jumlah sampel sebanyak 40 yang dipilih secara consecutive sampling, yang dibagi menjadi 2 kelompok yaitu 20 responden obesitas dan 20 responden berat badan normal. Kadar Resistin danTNF- $\alpha$ diperiksa dengan metode ELISA, kemudian data dianalisis dengan uji mann-whitney. Hasil penelitian median kadar resistin pada kelompok obesitas adalah $7,760(3,862$ - 40,620) ng/ml dan median kelompok berat badan normal adalah 2,696 (0,0154 - 6,1070) ng/ml. Median kadar TNF-a pada kelompok obesitas adalah 169,719 (152,312 - 451,04) ng/ml dan median kelompok berat badan normal 131,077(75,724 - 150,920) ng/ml. Secara statistik dengan uji mannwhitney diperoleh nilai $\mathrm{p}<0,001$. Simpulan studi ini ialah terdapat perbedaan bermakna antara kadar Resistin dan TNF- $\alpha$ pada obesitas dan berat badan normal.
\end{abstract}

Kata kunci: kadar resistin,TNF- $\alpha$, obesitas, berat badan normal, PEAL

\section{Abstract}

Maternal factors are the originator of Late Onset Of Preeclamsia. One of the maternal factor is Resistin, TNF- $\alpha$ which is associated with inflammation and insulin resistance. The objective of this study was to know the average variance of Resistin and TNF- $\alpha$ maternal levels between an obesity pregnancy women and who have a normal weight on Late Onset Of Preeclamsia. This study was comparative crosssectional, the study was conducted in RSUP Dr. M Djamil and Biomedical Laboratory Faculty of Medical Andalas University Padang on February 2016 - January 2017. The Number of samples were 40 which selected by consecutive sampling, which is divided into 2 groups. There were 20 obesity respondents and 20 respondents of normal weight. Resistin and TNF- $\alpha$ levels were examined by ELISA method, then the data were analyzed by mann-whitney test.The median results of resistance levels in the obesity group were 7.760 (3.862 - 40.620) $\mathrm{ng} / \mathrm{ml}$ and the median normal weight group was 2.696 (0.0154 - 6.1070) ng / $\mathrm{ml}$. Median levels of TNF- $\alpha$ in the obesity group were 169.719 (152.312 - 451.04) $\mathrm{ng} / \mathrm{ml}$ and median normal weight group 131.077 (75.724 - 150.920) ng / ml. Statistically obtained $p$ value <0.001. The conclusion is a significant difference between Resistin and TNF-a levels in obesity and normal weight.

Keywords: resistin level, TNF- $\alpha$, obesity, normal weight, late onset of preeclamsia 
Affiliasi penulis: 1. Prodi S2 Kebidanan Fakultas Kedokteran Universitas Andalas (FK Unand), 2.Bagian Penyakit Dalam FK Unand, 3.Bagian Obgin FK Unand, 4.Bagian Histologi FK Unand Korespondensi: Ira Suryanis

email: ierha_soeryanis@ymail.com, Telp: 081363118648

\section{PENDAHULUAN}

Preeklamsi merupakan penyulit utama dalam kehamilan dan penyebab utama morbiditas dan mortalitas ibu dan janin. ${ }^{1}$ Angka kematian Ibu yang disebabkan oleh preeklamsi masih tinggi. ${ }^{2}$

Penyakit ini masih merupakan disease of theory. Berbagai macam penelitian belum dapat menerangkan dengan jelas penyebab pastinya. Teori yang banyak dianut adalah: (1) teori kelainan vaskularisasi plasenta; (2) teori iskemia plasenta, radikal bebas dan disfungsi endotel; (3) teori intoleransi imunologik antara ibu dan janin; (4) teori adaptasi kardiovaskuler; (5) teori defisiensi gizi; (6) teori inflamasi.,

Analisis faktor resiko preeklamsi diperlukan untuk mengurangi dampak buruk kejadian preeklamsi. Adapun faktor resiko digolongkan menjadi 3 yaitu faktor instrinsik dan faktor ekstrinsik yang merupakan pencetus Preeklamsi Awitan Dini (PEAD) sedangkan faktor maternal merupakan pencetus Preeklamsi Awitan Lambat (PEAL). Salah satu faktor maternal adalah resistin, TNF-a yang dihubungkan dengan inflamasi dan resistensi insulin. 5,6

Resistin adalah adipose tissue specific secretory factor (ADSF), merupakan suatu hormon yang disekresi oleh jaringan adiposa yang menginduksi resistensi insulin di otot dan hati. Resistin diekspresikan di jaringan lemak abdominal dan juga diekspresikan di jaringan plasenta (terutama trofoblas), sumsum tulang, paru-paru dan sel inflamasi terutama pada monosit di sirkulasi dan juga disekresi oleh makrofag pada atheroma. Resistin distimulasi oleh keadaan inflamasi yang menghasilkan sitokin proinflamasi. ${ }^{5}$

Preeklamsi berhubungan dengan inflamasi dan resistensi insulin yang dipengaruhi oleh resistin yang kadarnya akan meningkat pada kehamilan dengan Obesitas. ${ }^{5}$

Berbagai penelitian dapat diperkirakan bahwa faktor inflamasi dan resistensi insulin yang dihubungkan dengan kadar resistin lebih dominan pada kelompok ibu hamil obesitas dibandingkan dengan kelompok ibu hamil yang tidak obesitas. $^{5}$

Tumor Necrosis Factor $\alpha(T N F-\alpha)$ adalah komponen sitokin utama yang berperan dalam proses imunomodulator dan respon inflamasi, yang disekresikan oleh makrofag dan sel adipose. Pada kasus resistensi insulin, TNF- $\alpha$ menghambat terjadinya signaling reseptor insulin pada jaringan adipose melalui reseptor TNF-a. Mediator inflamasi yang disekresikan oleh makrofag dan sel adipose berpengaruh terhadap kadar glukosa darah, diduga pada obesitas terjadi keadaan inflamasi kronik sistemik. ${ }^{7}$

Penelitian ini bertujuan untuk mengetahui perbedaan rerata kadar Resistin dan TNF- $\alpha$ maternal antara wanita hamil obesitas dan yang memiliki berat badan normal pada Preeklamsi Berat Awitan Lambat.

\section{METODE}

Penelitian telah dilakukan di kamar bersalin RSUP. Dr. M. Djamil dan di Laboratorium Biologi Molekuler Fakultas Kedokteran Universitas Andalas (FK-Unand) Padang selama satu tahun yang dimulai bulan februari 2016. Penelitian ini merupakan penelitian analitik komparatif dua kelompok tidak berpasangan dengan pendekatan cross sectional untuk menganalisis rerata kadar resistin danTNFa ibu hamil yang obesitas dengan yang memiliki 
berat badan normal pada preeklamsi berat awitan lambat. Populasi pada penelitian ini adalah semua ibu hamil yang obesitas dan yang memiliki berat badan normal dengan usia kehamilan > 34 minggu dengan diagnosis Preeklamsia Berat PEB yang di rawat inap di Kamar Bersalin RSUP. Dr. M. Djamil dengan jumlah sampel 40 sampel. Pengambilan sampel dilakukan menggunakan teknik consecutive sampling. Setiap ibu hamil yang obesitas dan berat badan normal dan PE yang memeriksakan kehamilannya ke rawat inap Rumah Sakit Dr. M. Djamil memenuhi kriteria inklusi dan eksklusi dijadikan sampel.

Ibu yang memenuhi syarat penerimaan diberikan penjelasan oleh peneliti mengenai penelitian (information for consent) dan menyatakan SETUJU untuk ikut berpartisipasi dalam penelitian ini dengan menandatangani lembar persetujuan yang sudah dibaca dan dipahami sebelumnya (informed consent). Darah vena yang telah diambil dari ibu hamil selanjutnya dimasukkan kedalam tabung sentrifuge (vacutainer) dengan cara gagang spuit dibiarkan mengeluarkan darah dengan sendirinya dari tabung spuit. Darah yang ada di dalam vacutainer diletakkan pada rak tabung agar terhindar dari guncangan dan tetap dalam posisinya, selanjutnya didiamkan selama $15-20$ menit. Darah disentrifuge dengan kecepatan 2000-3000 rotasi per menit (rpm) selama 15-20 menit di Laboratorium Biomedik FK-UNAND. Pengambilan serum dari hasil sentrifuge menggunakan mikro pipet, selanjutnya serum yang diperoleh dimasukkan ke dalam mikro tube yang sudah diberi kode sesuai identitas responden.

Sampel darah yang didapatkan pada malam hari tetap dimasukkan ke dalam vacutainer. Serum darah tersebut dapat bertahan selama 2 jam jika berada pada suhu ruangan $\left(25^{\circ} \mathrm{C}\right)$, dan dapat bertahan selama 1 malam jika berada pada freezer/cool box (suhu $4^{0} \mathrm{C}$ ). Sampel serum segera dikirim ke laboratorium Biomedik FK-UNAND Padang untuk disimpan di dalam lemari pendingin dengan suhu $-80^{\circ} \mathrm{C}$ (dapat bertahan 6 bulan).

Pemeriksaan resistin dan TNF- $\alpha$ menggunakan metode ELISA, dilakukan di laboratorium Biomedik FK Unand. Penelitian ini telah mendapatkan persetujuan etik dari Panitia Etik Penelitian di Fakultas Kedokteran Universitas Andalas. Data resistin dan TNF- $\alpha$ yang diperoleh dianalisis dengan uji $\mathrm{T}$ tidak berpasangan.

Tabel 1. Rerata kadar resistin

\begin{tabular}{lccc}
\hline & \multicolumn{2}{c}{ Kelompok } & \\
\cline { 2 - 3 } Variabel & Obesitas & BB Normal & Nilai $\rho$ \\
& $(\mathbf{2 0 )}$ & $\mathbf{( 2 0 )}$ & \\
\cline { 2 - 3 } & Median & Median & \\
\hline Kadar & $($ min-max $)$ & $($ min-max $)$ & \\
Resistin & 7,760 & 2,696 & 0,000 \\
(ng/ml) & $(3,862-$ & $(0,0154-$ & \\
\hline
\end{tabular}

Berdasarkan Tabel 1 dapat dilihat bahwa median kadar resistin lebih tinggi pada kelompok obesitas dari pada kelompok berat badan normal pada Preeklamsi Berat Awitan Lambat (PEAL). Median kelompok obesitas adalah7,760 (3,862 $40,620) \mathrm{ng} / \mathrm{ml}$ dan median kelompok berat badan normal adalah2,696 $(0,0154-6,1070) \mathrm{ng} / \mathrm{ml}$. Secara statistik terdapat perbedaan bermakna antara kedua kelompok tersebut.

Tabel 2. Rerata kadar TNF- $\alpha$

\begin{tabular}{lccc}
\hline & \multicolumn{2}{c}{ Kelompok } & \\
\cline { 2 - 3 } Variabel & Obesitas & BB Normal & Nilai $\rho$ \\
& $(20)$ & (20) & \\
\cline { 2 - 3 } & Median & Median & \\
\hline Kadar & (min-max) & (min-max) & \\
TNF- $\alpha$ & 169,719 & 131,077 & 0,000 \\
(ng/ml) & $(152,312-$ & $(75,724-$ & \\
\hline
\end{tabular}


Berdasarkan Tabel 2 dapat dilihat bahwa median kadar TNF- $\alpha$ lebih tinggi pada kelompok obesitas dari pada kelompok berat badan normal pada Preeklamsi Berat Awitan Lambat (PEAL). Median kelompok obesitas adalah 169,719 $(152,312$ - 451,04)ng/ml dan median kelompok berat badan normal131,077 (75,724 - 150,920) $\mathrm{ng} / \mathrm{ml}$. Secara statistik terdapat perbedaan bermakna rerata kadar TNF- $\alpha$ antara dua kelompok tersebut.

\section{PEMBAHASAN}

\section{Rerata kadar Resistin antara PEAL obesitas dengan berat badan normal}

Rerata kadar resistin serum maternal pada kelompok PEAL dengan obesitas adalah 7,760 $(3,862$ - 40,620) ng/ml, sedangkan pada kelompok PEAL dengan berat badan normal adalah 2,696 (0,0154 - 6,1070) ng/ml. Uji statistik menunjukkan nilai $p<0,005$, menunjukkan bahwa rerata kadar resistin serum maternal pada PEAL dengan obesitas lebih tinggi secara signifikan dibandingkan dengan PEAL dengan berat badan normal (Tabel 1).

Noureldeen et al (2014) melaporkan hasil yang sama di mana rerata kadar resistin serum maternal lebih tinggi pada preeklamsia dengan obesitas dibandingkan dengan berat badan normal dimana terjadi peningkatan risiko PE dua kali lipat pada BMI 26 dan tiga kali lipat pada BMI >30 dibandingkan dengan normal. Hal ini berhubungan dengan peningkatan resistensi insulin, dan respon inflamasi sistemik yang terjadi pada preeklamsia, terutama preeklamsia awitan lambat. ${ }^{7}$

Penelitian Noureldeen et al (2014) juga menghasilkan bahwa ibu hamil dengan preeklamsia $\mathrm{BMI} \geq 30(\mathrm{n}=50)$, dan hamil normal BMI $\geq 30(n=50)$. Hasilnya rerata kadar resistin serum maternal lebih tinggi pada wanita dengan preeklamsia $12.04 \pm 0.973(8,21$ - 19,61) dibandingkan dengan wanita hamil normal7.35 \pm $1.195(1,10-22,34) p=0,041^{7}$

Resistin merupakan suatu hormon yang disekresi jaringan adiposa yang menginduksi resistensi insulin di otot dan hati. Resistin distimulasi oleh keadaan inflamasi yang menimbulkan sitokin proinflamasi. Resistin akan berperan dalam berbagai keadaan inflamasi seperti penyakit jantung koroner, penyakit ginjal kronis, dan sirosis hepatis, serta resistensi insulin melalui aktivasi sitokin proinflamasi yang berbeda tergantung organ yang dipengaruhi. ${ }^{7}$

Resistensi insulin dan inflamasi adalah dua keadaan yang berhubungan dengan preeklamsia. Kedua faktor ini berhubungan dengan peran resistin melalui pelepasan sitokin proinflamasi, sehingga pengkajian hubungan antara resistin dengan preeklamsia, dijembatani oleh kedua hal tersebut yang merupakan faktor maternal yang mempengaruhi terjadinya preeklamsia. Resistin lebih terkait dengan PEAL karena merupakan faktor maternal, sehingga diperkirakan kadar resistin akan meningkat pada PEAL. ${ }^{4}$

Inflamasi dan resistensi insulin berhubungan dengan kejadian PEAD dan PEAL telah diteliti oleh Yusrawati (2015) yang membandingkan antara HOMA-IR dan hs-CRP pada PEAD dengan PEAL. Peneliti mendapatkan hasil rerata HOMA-IR dan hs-CRP lebih tinggi pada kelompok PEAL dibandingkan kelompok PEAD yaitu HOMA IR: 4,86 $\pm 5,50$ vs $3,99 \pm$ 5,97, dan hsCRP: $38,67 \pm 123,08 \mathrm{mg} / \mathrm{L}$ vs 26,54 $\pm 34,7 \mathrm{mg} / \mathrm{L}$, memperlihatkan bahwa faktor inflamasi dan resistensi insulin lebih dominan pada kelompok PEAL dibandingkan dengan kelompok PEAD. ${ }^{8}$ 


\section{Rerata kadar TNF- $\alpha$ antara PEAL obesitas dengan berat badan normal}

Rerata kadar TNF- $\alpha$ serum maternal pada kelompok PEAL dengan riwayat obesitas adalah 169,719 (152,312 - 451,049) $\mathrm{ng} / \mathrm{ml}$, sedangkan pada kelompok PEAL dengan berat badan normal adalah 131,077 $(75,724-150,920 \mathrm{ng} / \mathrm{ml}$. Uji statistik menunjukkan nilai $p<0,005$, menunjukkan bahwa rerata kadar TNF- $\alpha$ serum maternal pada PEAL dengan riwayat riwayat obesitaslebih tinggi secara signifikan dibandingkan dengan PEAL dengan berat badan normal. (Tabel 2).

Noureldeen et al (2014), melakukan penelitian cross sectional yang dilakukan pada kelompok ibu hamil, yaitu hamil dengan preeklamsia $\mathrm{BMI} \geq 30 \quad(\mathrm{n}=50)$, dan hamil normal BMI $\geq 30 \quad(n=50)$. Hasilnya mean kadar TNF- $a$ serum maternal lebih tinggi pada wanita dengan preeklamsia $15.23 \pm 0.674(11,00-19,90)$ dibandingkan dengan wanita hamil normal 12.84 $\pm 0.348(11,3-17,00) p=0,021{ }^{7}$

Senada dengan penelitian yang dilakukan oleh Sandra (2008) menjelaskan tentang konsentasi TNF adalah $0.97 \pm 0.11(\mathrm{pg} / \mathrm{ml} \pm$ SEM) pada kehamilan normal, $1.01 \pm 0.10$ pada obesitas, $1.43 \pm 0.11$ pada preeklamsi dan $1.16 \pm 0.11$ pada wanita obesitas yang preeklamsi dengan nilai $p=0.04$. Artinya bahwa konsentrasi TNF- $\alpha$ lebih tinggi pada wanita obesitas yang preeklamsi. ${ }^{9}$

Penelitian oleh Stupin dan Arbian (2014) menjelaskan bahwa 3,76 peningkatan resiko kehamilan diabetes ditemukan pada wanita yang obesitas, karena obesitas sebelum kehamilan berhubungan dengan perubahan yang terjadi pada endokrin ibu dan janin. Jaringan adiposa menghasilkan TNF- $\alpha$, interleukins dan leptin serta meningkatkan kerja adipokin. Kehamilan, overweight dan obesitas dapat menyebkan resistensi insulin. Resistensi Insulin dan obesitas meningkatkan proses inflamasi dan disfungsi vaskuler sehingga dapat menyebabkan preeklamsi pada wanita hamil obesitas. ${ }^{10}$

Tumor Necrosis Factor Alpha (TNF- $\alpha$ ) terbukti juga merupakan modulator respon imun yang kuat memperantai induksi molekul adhesi, sitokin lain dan aktifasi netrofil. Disamping berfungsi meningkatkan ekspresi molekul adhesi yang memudahkan leukosit melekat pada permukaan endotel, dan merangsang sel fagosit mononucler untuk mensekresi chemokine, serta mengativasi leukosit, TNF yang diproduksi dalam jangka panjang dengan konsentrasi rendah mengakibatkan tissue remodeling. Tumor Necrosis Factor (TNF) dapat berfungsi sebagai faktor angiogenesis dan membentuk pembuluhan darah baru dan dapat berfungsi sebagai faktor pertumbuhan fibroblas yang bengakibatkan pembentukan jaringan ikat. Bila produksi TNF tetap berlanjut, jaringan tersebut dapat merupakan jaringan limfosit baru dimana berkumpul limfosit $B$ dan limfosit $T$. $^{11}$

Sekresi TNF- $\alpha$ yang berlebih akan merusak sel endotel, menyebabkan kerusakkan pembuluh darah, mengurangi aliran darah regional, dan meningkatkan permeabilitas endothelium. Aktivasi TNF- $\alpha$ dimediasi oleh sistem kekebalan tubuh yang dapat mengakibatkan sekresi zat vasoaktif oleh karena cedera endotel dan menyebabkan permeabilitas vaskular dan koagulasi intravaskular. TNF- $\alpha$ merupakan sitokin pro inflamasi. ${ }^{11}$

Sumber produksi TNF- $\alpha$ pada preeklampsia adalah neutrofil dan monosit pada plasenta. Salah satu mekanisme preeklampsia adalah faktor yang berasal dari plasenta yang merangsang monosit dan neutrofil untuk memproduksi TNF- $\alpha$ yang dapat menyebabkan gangguan endotel. Pada temuan ini menunjukkan bahwa serum TNF- $\alpha$ meningkat hal ini dapat menjadi bagian dari patogenesis 
preeklampsia. Pada kehamilan normal, TNF-a dapat memodifikasi pertumbuhan dan invasi trofoblas pada arteri spiralis ibu dan memberikan kontribusi untuk plasentasi abnormal, stres oksidatif dan gangguan endotel. ${ }^{12}$

TNF- $\alpha$ merupakan komponen sitokin utama yang berperan dalam proses imunomodulator dan respon inflamasi, yang disekresikan oleh makrofag dan sel adiposa. Pada kasus resistensi insulin, TNF- $\alpha$ menghambat terjadinya signaling reseptor insulin pada jaringan adiposa melalui reseptor TNF-a. ${ }^{12}$

Mediator inflamasi yang disekresikan oleh makrofag dan sel adipose berpengaruh terhadap kadar glukosa darah, diduga pada obesitas terjadi keadaan inflamasi kronik sistemik. ${ }^{12}$

\section{SIMPULAN}

Rerata kadar resistin dan TNF- $\alpha$ pada wanita hamil yang obesitas lebih tinggi dari pada yang memiliki berat badan normal pada Preeklamsi Berat Awitan Lambat

\section{UCAPAN TERIMA KASIH}

Terima kasih kepada Kepala dan Staf Laboratorium Biomedik FK-Unand yang telah membantu pemeriksaan sampel.

\section{DAFTAR PUSTAKA}

1. Cunningham FG, Leveno $\mathrm{KJ}$, Bloom SL, Spong CY, Dhase JS, Hoffman BL, et al. William Obstetrics. 24th edition. New York: Mc Graw Hill Education; 2014

2. Keman, K, Perbedaan ekspresi p53, Bcl-2 dan indeks apoptosis trofoblas pada preeklampsia/eklampsia dan kehamilan normal. Majalah Obstetri Ginekologi Indonesia. 2009;33(3):151-9.

3. Steegers E, Dadelszen P, Duvekot J, Pijnenborg R. Pre-eclampsia. The Lancet. 2010;376:631-44
4. Park, Ahima R. Increase in glucose 6 phosphate dehydrogenase in adipocytes stimulates oxidative stress and inflammatory signals. Diabetes. 2006;55:2939-49.

5. Benomar Y, Gertler A, De Lacy P, Crepin D, Hamouda $H$, Riffault $L$, et al. Central resistin over exposure induces insulin resistance through toll-like receptor 4.American Diabetes Association. 2013;62:102-14.

6. Ronti T, Lupatelli G, Mannarino E. The endocrine function of adipose tissue: an update. Clinical Endocrinology. 2006;64:35565.

7. Noureldeen AFH, Qusti SY, Al-seeni MN. Serum leptin, adiponectin, resistin, visfatin and inflammatory cytokines in normal weight and obese women with normal pregnancy and with preeclampsia. Life science journal. 2014;11(5):17-23.

8. Yusrawati. Peran takik diastolik arteri uterina sebagai faktor risiko dan perbedaan resistensi insulin, ADMA, HS-CRP dan adiponektin antara preklamsi awitan dini dan preeklamsi awitan lambat (disertasi). Padang: Prodi S3 Biomedik Fakultas Kedokteran Universitas Andalas; 2015.

9. Sandra A, Power RW, Robert J. A Comparison of circulating TNF alpha in obese and leanwomen with and without preeclampsia. Hypertens Pregnancy. 2008; 27(1):39-48

10.Stupin JH, Arbian B. Overweight and Obesity before, during and after Pregnancy.MCBI. 2014;74(7):639-45.

11.Wang A. Preeclampsia: The role of angiogenic factors in its pathogenesis. Physiology. 2008;24:147-58.

12.Sidani M. Preeclampsia, a new perspective. Mej Anesth. 2011;21(2):207-16. 